\title{
Sehat Bermedia Sosial Saat Pandemi Covid-19 Melalui Pelatihan Daring Bagi Ibu Rumah Tangga
}

\author{
https://doi.org/10.32509/abdimoestopo.v4i02.1451 \\ Rini Riyantini ${ }^{*}$, Rudhy Ho Purabaya ${ }^{2}$ \\ Program Studi Komunikasi Pembangunan, Universitas Pembangunan Nasional "Veteran" \\ Jl. RS. Fatmawati Raya, Jakarta, Indonesia \\ *Email Korespondensi: riniriyantini@upnvj.ac.id
}

\begin{abstract}
The internet is not only a medium for sending e-mails or for looking for news, but through the internet, people get to know social media with a variety of content that can be accessed by everyone, including housewives. Social media is not only a communication tool but also a source of information that can be accessed quickly, as well as information about covid 19. Hoax about covid 19 are also circulating on social media which can have a psychological impact. This community service aims to provide an understanding of how to use healthy social media by educating the Housewife community of the PKK group, Rangkap Jaya Village, Pancoran Mas District, Depok City, which has a whats app group. The material provided includes the characteristics of hoax, provisions for the dissemination of hoax and sanctions based on the law on information and electronic transactions as well as attitudes in using social media. Submission of material online through gmeet and packaged in the form of short messages that are uploaded through social media groups on a regular basis. Pretest and post test were conducted to measure the level of success in giving the material. The results of the post test showed that there was a change in the understanding and attitude of housewives towards the dissemination of hoax information on social media.
\end{abstract}

Keywords: Social media, hoax, attitude

\begin{abstract}
Abstrak - Internet tidak hanya menjadi medium untuk menyampaikan surel ataupun untuk mencari berita saja, tetapi melalui internet masyarakat mengenal media sosial dengan berbagai konten yang dapat diakses semua orang, termasuk ibu rumah tangga. Media sosial tidak hanya menjadi alat komunikasi tetapi sekaligus sebagai sumber informasi yang bisa diakses dengan cepat, begitu juga informasi tentang covid 19. Ho.aks tentang covid 19 banyak beredar juga di media sosial yang dapat memberikan dampak secara psikologis. Pengabdian masyarakat ini bertujuan memberikan pemahaman bagaimana bermedia sosial yang sehat dengan mengedukasi komunitas Ibu Rumah Tangga kelompok PKK Kelurahan Rangkapan Jaya, Kecamatan Pancoran Mas, Kota Depok yang memiliki grup whats app. Materi yang diberikan meliputi ciri ciri ho.aks, ketentuan penyebarluasan ho.aks dan sanksi berdasarkan undang undang informasi dan transaksi elektronik serta sikap dalam menggunakan media sosial. Penyampaian materi secara daring melalui gmeet serta dikemas dalam bentuk pesan singkat yang diunggah melalui grup media sosial secara berkala. Pretest dan postes dilakukan untuk mengukur tingkat keberhasilan pemberian materi. Hasil post test menunjukkan terdapat perubahan pemahaman dan sikap ibu Rumah Tangga terhadap penyebaran informasi ho.aks pada media sosial.
\end{abstract}

Kata Kunci: Media sosial, ho.aks, sikap

\section{PENDAHULUAN}

IndiHome dan Biznet mencatat lonjakan lalu lintas (traffic) data dan pengguna baru sejak diberlakukan bekerja dari rumah (work from home/WFH) dan belajar dari rumah, jumlah pengguna baru juga meningkat sebanyak 30 persen dibandingkan sebelumnya (CNN Indonesia, 2020). Internet tidak lagi hanya menjadi medium untuk menyampaikan surel ataupun sekedar mencari berita saja, tetapi kini dengan internet masyarakat mulai mengenal yang dinamakan media sosial (Twitter, Instagram, Facebook, YouTube, dsb) dan pesan instan (WhatsApp, 
LINE, Blackberry Messenger, dsb). Fasilitas dan konten internet yang semakin berkembang, semakin banyak menyediakan pilihan menyebabkan pemanfaatan internet yang semakin beragam pada masing-masing individu. Pemanfaatan internet tersebut tidak hanya tergambar dari durasi dan frekuensi mengakses internet, tetapi juga fasilitas apa yang dimanfaatkan oleh pengguna internet saat menggunakan internet (Novianti, 2018).

Penggunaan media sosial menjadi prioritas bagi setiap orang terutama para ibu ketika pandemi sebagai alat komunikasi yang banyak membantu dalam menjalankan fungsinya sebagai ibu rumah tangga, mulai dari belanja sayuran sampai dengan belanja keperluan lainnya, bahkan grup di media sosial secara signifikan bertambah. Media sosial tidak hanya digunakan sebagai alat komunikasi saja tetapi sekaligus sebagai sumber informasi yang bisa diakses dengan cepat, begitu juga terkait informasi covid 19.

Pandemi covid 19 yang menyebabkan pembatasan-pembatasan juga dapat berdampak psikologis. Hasil penelitian terhadap penduduk Istanbul, sekitar 64,1 persen ditemukan dengan kelelahan psikologis akibat efek pandemi Covid-19 (CNN Indonesia, 2021). Boldsky dalam studinya menyoroti bahwa perubahan dalam praktik normal seperti menghindari tempat berkerumun, menjaga jarak secara fisik, stres karena mencuci tangan sepanjang waktu, dan peningkatan informasi tentang penularan virus melalui media juga meningkatkan pandemic fatigue (CNN Indonesia, 2021). Kekhawatiran masyarakat secara psikologis terhadap penyebaran virus covid 19 menyebabkan peningkatan pencarian informasi melalui media sehingga penggunaan internet signifikan semakin meningkat.

Indonesia merupakan salah satu negara pengguna internet terbanyak di dunia sehingga, tidak heran masyarakat menggunakan internet sebagai sarana informasi, sayangnya karena kebebasan Internet cukup banyak ho.aks yang tersebar di sekitar kita (Kompasiana, 2020). Pemberlakuan pembatasan sosial, bekerja dari rumah dan belajar dari rumah menyebabkan kejenuhan dengan rutinitas semua aktivitas masyarakat dilakukan melalui media yang sarat dengan segala informasi. Dampak meningkatnya penggunaan internet melalui media sosial tidak hanya psikologis tetapi juga secara ekonomi dan sosial. Penggunaan internet harus disertai dengan pengetahuan cara menggunakan internet yang baik sehingga tidak terjebak dengan berita palsu (ho.aks).

Ho.aks merupakan informasi yang direkayasa untuk menutupi informasi sebenarnya, jalan utama untuk mengantisipasi ho.aks adalah membangun kompetensi publik dalam menghadapi luapan banjir informasi (Gumilar, 2017). Saat peristiwa global terjadi, semua orang di seluruh dunia akan mencari dan mengakses informasi peristiwa tersebut, begitu pula dengan bencana pandemi yang merupakan peristiwa yang baru sehingga mendorong setiap orang untuk berusaha mencari informasi tentang pandemi covid 19. Informasi covid 19 pun tidak lepas dari ho.aks, mulai dari proses penyebaran virus, cara pencegahan sampai penanganan dan kebijakan penanganan pun tidak luput dari berita ho.aks. Literasi media menjadi keharusan bagi seluruh pengguna media di seluruh lapisan masyarakat, anak-anak, remaja sampai orang tua tidak bisa lepas dari media dalam menjalani kehidupannya.

Literasi media juga merupakan proses yang harus berkelanjutan seiring dengan perkembangan teknologi informasi. Ibu-ibu saat pandemi memiliki peran strategis dalam literasi media, karena tanggung jawabnya untuk mendampingi putera puterinya dalam belajar, memenuhi kebutuhann rumah tangganya bahkan kegiatan sosial lainnya dilakukan melalui media. Ibu-ibu di wilayah perkotaan lebih banyak mengakses media sehingga lebih banyak terpapar ho.aks. Orang kota lebih mudah diserang ho.akss karena mereka lebih akrab dengan penggunaan media sosial (Kompas.com, 2019), sehingga memiliki kecenderungan untuk meneruskan informasi tersebut kepada kolega dan jaringan komunikasinya di media sosial. Subiakto menyatakan bahwa masyarakat yang berpendidikan dan beragama fanatik juga lebih banyak terkena ho.aks (Farissa dan Galih dalam Kompas.com, 2019). Perlu memberikan penyuluhan bagaimana cara menggunakan media sosial yang sehat terutama dalam memahami 
dan menyikapi informasi ho.aks tentang pandemi covid 19. Penyuluhan yang dilakukan menjadi merupakan salah satu cara literasi media. sehingga dapat meningkatkan pemahaman kepada pengguna media sosial terutama ibu rumah tangga.

a. Pendidikan Masyarakat

\section{METODE PELAKSANAAN}

Pendidikan masyarakat terkait pemahaman penggunaan media sosial yang sehat dilakukan melalui penyuluhan secara lisan dan tertulis berdasarkan observasi awal kebutuhan materi yang diperoleh dari observasi pemetaan awal kemampuan khalayak dalam memahami dan menyikapi ho.aks.

b. Pre test dan post test

Dilakukan untuk memperoleh pemetaan tingkat pemahaman khalayak sasaran dalam menggunakan media sosial yang sehat serta sebagai pengukuran tingkat keberhasilan kegiatan pengabdian kepada masyarakat sehat bermedia sosial. Metode dan tahapan kegiatan yang dilakukan seperti pada tabel 1 .

Tabel 1. Metode dan Tahapan Kegiatan

\begin{tabular}{|c|c|c|c|}
\hline No & Metode & Tahapan Kegiatan & Waktu \\
\hline 1 & $\begin{array}{l}\text { Pre test melalui google } \\
\text { form yang diunggah di } \\
\text { grup what.app }\end{array}$ & $\begin{array}{l}\text { Pengukuran tingkat pemahaman ciri- } \\
\text { ciri ho.aks, ketentuan } \\
\text { penyebarluasan, sikap }\end{array}$ & $\begin{array}{l}7 \text { (tujuh) hari } \\
\text { kerja }\end{array}$ \\
\hline 2 & $\begin{array}{l}\text { Penyuluhan daring } \\
\text { tatap muka ciri-ciri } \\
\text { ho.aks, ketentuan } \\
\text { penyebarluasan dan } \\
\text { kiat bermedia sosial } \\
\text { yang sehat melalui } \\
\text { google meet }\end{array}$ & $\begin{array}{l}\text { Penyiapan materi dalam bentuk } \\
\text { power point dan beberapa contoh } \\
\text { kasus ho.aks. }\end{array}$ & $\begin{array}{l}1 \text { (satu) kali } \\
\text { pertemuan } \\
\text { dengan durasi } 60 \\
\text { menit }\end{array}$ \\
\hline 3 & $\begin{array}{l}\text { Penyuluhan daring non } \\
\text { tatap muka melalui } \\
\text { unggahan materi dalam } \\
\text { berntuk power point } \\
\text { dan capture }\end{array}$ & Mengunggah materi penyuluhan & $\begin{array}{l}4 \text { (empat) kali } \\
\text { unggahan selama } \\
\text { I (satu) bulan }\end{array}$ \\
\hline 4 & $\begin{array}{l}\text { Post test melalui google } \\
\text { form yang diunggah di } \\
\text { grup what.app }\end{array}$ & $\begin{array}{l}\text { Pengukuran tingkat keberhasilan } \\
\text { pemahaman dengan mengukur } \\
\text { perubahan sikap bermedia sosial }\end{array}$ & $\begin{array}{l}7 \text { (tujuh) hari } \\
\text { kerja }\end{array}$ \\
\hline
\end{tabular}

Sumber: PkM, 2021

\section{HASIL DAN PEMBAHASAN}

Pelaksanaan kegiatan PkM sehat bermedia sosial saat pandemi covid 19 bagi ibu rumah tangga yang tergabung pada kelompok Pemberdayaan dan Kesejahteraan Keluarga (PKK) di Kelurahan Rangkapan Jaya, Kecamatan Pancoran Mas Kota Depok bertujuan untuk meningkatkan pemahaman terhadap penerimaan informasi tentang pandemi covid 19 khususnya yang beredar di media sosial. Selain informasi yang akurat dan valid, banyak informasi yang sifatnya menyesatkan sehingga dapat menimbulkan peningkatan kecemasan dan kepanikan yang berefek psikologis. Efek psikologis ini akan berpengaruh terhadap kondisi fisik yang mengakibatkan menurunnya fungsi imun, sehingga penting untuk membantu memberikan penyuluhan pengenalan ho.aks bagi kelompok ibu-ibu PKK. Penyuluhan dilakukan secara daring menggunakan googlemeet selama 60 menit mengingat kondisi pandemi yang tidak memungkinkan untuk bertatap muka langsung, sehingga dipilih ibu-ibu PKK yang memiliki grup what.app (WA grup) sebanyak 47 orang. Selanjutnya materi diberikan secara tertulis 
dengan mengunggah pada grup what.app secara periodik setiap hari minggu selama satu bulan (4 kali unggah). Materi penyuluhan yang diberikan meliputi :

a. Ciri-ciri ho.aks yang meliputi menciptakan kebencian, sumber tidak jelas, pesan sepihak, pinjam nama orang atau media, fanatik, provokatif, penjulukan, minta diviralkan, data sangat teknis, sembunyikan fakta, tidak jelas sumbernya serta manipulasi foto dan keterangan.

b. Menggunakan media sosial yang terkait dengan ketentuan penyebaran luasan ho.aks, pencemaran nama baik dan penghinaan, serta ujaran yang menyinggung SARA (pasal 27,28, 29 UU ITE) serta sanksinya hukuman penjara 6-12 tahun atau denda 1-2 milyar rupiah (pasal 45 UU ITE).

c. Sikap dan reaksi ketika menerima informasi di media sosial yang aman dengan materi pengenalan informasi ho.aks meliputi identifikasi, eksplorasi, seleksi dan organisasi.

Penyuluhan ini dilakukan sebagai salah satu teknik dalam literasi media. Hasil penelitian Novianti (2018) menyatakan bahwa semakin baik kemampuan literasi media responden semakin banyak pula fitur internet yang diketahui, sehingga otomatis semakin banyak pula frekwensi penggunaan internet, sedangkan responden dengan kemampuan literasi media yang lebih rendah, cenderung hanya memanfaatkan internet untuk chatting bersama teman dan kerabatnya. Rahmawan (2018) memperkuat dengan menyatakan bahwa penetrasi media sosial tinggi, namun tingkat literasi media yang rendah membuat informasi yang negatif serta juga ho.aks berkembang dan tersebar di masyarakat. Minimnya pengetahuan akan konten media yang positif di kalangan anak muda, menjadikan mereka lebih banyak mendapatkan dampak negatif dari akses internet. Literasi tidak terbatas sebagai kemampuan membaca dan menulis saja, tetapi harus lebih mampu mengkonstruksi muatan yang positif dalam memanfaatkan media sosial (Hamzah dan Putri, 2020).

Pentingnya literasi media dapat memberikan pemahaman terhadap pemanfaatan media tidak hanya sebagai alat komunikasi tanpa pemahaman konten informasi. Banyak informasi yang telah dikirim berkali-kali sehingga sudah tidak dapat ditelusuri lagi sumbernya menerpa kita, diperlukan daya saring untuk memilih mana informasi yang perlu diterima mana yang harus dihindari. Pandemi covid 19 memaksa masyarakat untuk melek digital merupakan hal positif, tetapi peningkatan pemanfaatan media digital juga memberikan peluang kepada penggunanya mengakses informasi yang sarat dengan ho.aks. Rendahnya literasi media mengakibatkan adanya penyalahgunaan media sosial seperti berita ho.aks (Cindosari, et al, 2020).

Agar pemanfaatan media digital sesuai dengan harapan perlu dilakukan literasi yang salah satunya dilakukan dalam bentuk pelatihan dan pendampingan pemanfaatan internet sebagai media pembelajaran berbasis e-learning, sehingga mampu mewujudkan kegiatan pembelajaran yang aktif, inovatif, kreatif, dan menyenangkan bagi siswa (Nurmala, 2018). Setiap kelompok khalayak memiliki kepentingan yang berbeda dalam menggunakan media digital pada saat pandemi. Sesuai tujuannya, kegiatan PkM memiliki khalayak sasaran ibu rumah tangga yang tergabung dalam kelompok Pemberdayaan dan Kesejahteraan Keluarga (PKK) yang memiliki grup whats. app pada media sosial, sehingga dalam kondisi pandemi komunikasi dapat tetap berlangsung secara daring.

Hasil pelaksanaan kegiatan pengabdian kepada masyarakat ini diukur berdasarkan tingkat keberhasilan kegiatan penyuluhan materi dengan membandingkan perolehan skor pre test dan pos test yang diberikan, serta memperhatikan respon melalui jawaban dan komentar dalam WA grup ketika mengunggah pesan materi yang disajikan pada gambar diagram pie 1 , 2, 3. Indikator pengukuran disesuai dengan tujuan dan materi yang disampaikan yaitu pengetahuan tentang hoax, pengetahuan tentang ketentuan dalam bermedia sosial terutama pasal 27, 28 dan 45 UU ITE dan sikap dalam menerima ho.aks. Ho.aks merupakan kepalsuan yang sengaja dibuat menggunakan data, foto dan kutipan orang untuk menyaru sebagai 
kebenaran sehingga dianggap orang yang membacanya sebagai sebuah kebenaran (Prasetyo, 2019). Hasil penelitian CIGI 14 menyebutkan sebesar 67 persen Facebook sebagai media penyebar ho.aks, 65 persen, dan situs web lain sebesar 60 persen (Monggilo et al, 2020). Materi yang berhubungan dengan pengenalan ho.aks mengacu kepada ciri-ciri dari informasi yang terdapat pada konten tampilan ho.aks yang dikemukakan oleh Prayitno (Beritasatu.com, 2019), serta 8 (delapan) tahapan praktik pengenalan informasi ho.aks yang dikenal dengan E8 (Empowering 8) yang dimodifikasi menjadi 4 langkah (Rahmawati, 2019) yaitu:

1. Identifikasi topik/subjek, sasaran audiens,format yang relevan, jenis-jenis sumber;

2. Eksplorasi sumber dan informasi yang sesuai dengan topik;

3. Seleksi dan merekam informasiyang relevan, dan mengumpulkan kutipan-kutipan yang sesuai;

4. Organisasi, evaluasi dan menyusun informasi menurut susunan yang logis, membedakan antara fakta dan pendapat, dan menggunakan alat bantu visual untuk membandingkan dan mengkontraskan informasi;

Literasi media menjadi tanggung jawab seluruh pengguna media sosial, yang harus dilakukan secara berkelanjutan sesuai dengan perkembangan informasi dan perkembangan media. Penggunaan media sesuai dengan profesi dapat sekaligus memberikan literasi media kepada pada pembacanya,seperti konten kreator, youtuber bahkan pustakawan yang selalu menggunakan media. Ganggi (2018) menyatakan bahwa media sosial lekat dengan pustakawan, sehingga pustakawan memiliki kewajiban dan tanggung jawab dalam memberikan contoh literasi media.

Pengukuran tingkat keberhasilan kegiatan pengabdian kepada masyarakat dilakukan melalui tahapan sebagai berikut.

a. Pengukuran Hasil Pre Test

Pre test dalam bentuk pertanyaan multiple choice diberikan kepada peserta penyuluhan yang memiliki whats app grup secara online menggunakan google form. Setiap butir pertanyaan diberikan bobot skor 1 untuk jawaban yang benar (tahu) dan bobot 0 jika pilihan jawaban yang diisi salah (tidak tahu). Pertanyaan pre test meliputi pemahaman ciri-ciri ho.aks, ketentuan penggunaan media sosial berdasarkan undang undang ITE, serta sikap pengguna media sosial terhadap ho.aks. Perhitungan akhir hasil pre test disajikan dalam bentuk persentase dengan menggunakan diagram pie (gambar 1). Pengisian pre test dilakukan oleh seluruh anggota what app grup bentuk kemudian menghitung berapa jumlah orang yang tingkat pengetahuannya baik dibagi jumlah seluruh anggota grup yang mengisi pre test yang kebetulan seluruh anggota dapat memberikan respon terhadap pre test yang dilakukan, karena sebelumnya diberikan pengantar.

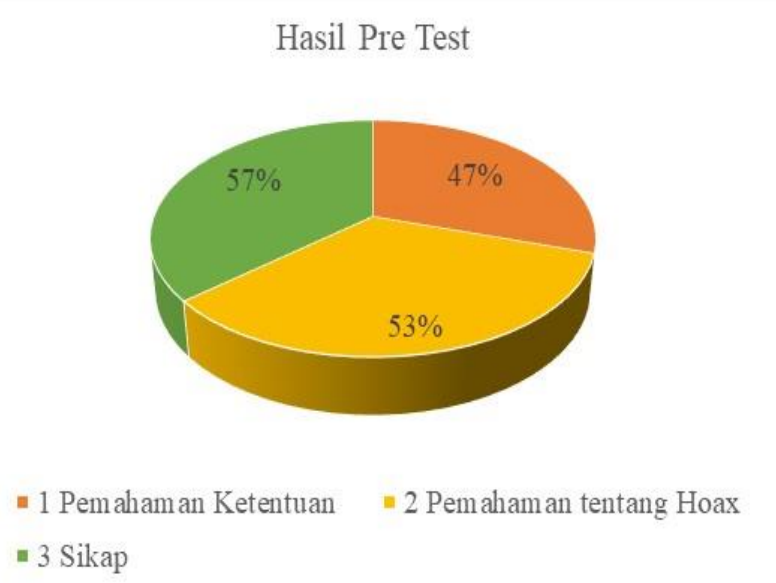

Gambar 1: Hasil pre test (Sumber: Analisis pre test PkM, 2021) 
b. Pengukuran Hasil Post Test

Post test dilakukan setelah 1 bulan unggahan pesan materi dilakukan untuk menghindari bias jika langsung diberikan post test begitu materi diberikan. Pemberian materi juga diunggah 1 minggu setelah pre test dilakukan dan setelah penyuluhan secara daring dilakukan, sehingga khalayak sasaran berkomunikasi secara normal pada Wa grup. Hasil post test seperti pada diagram pie 2 .

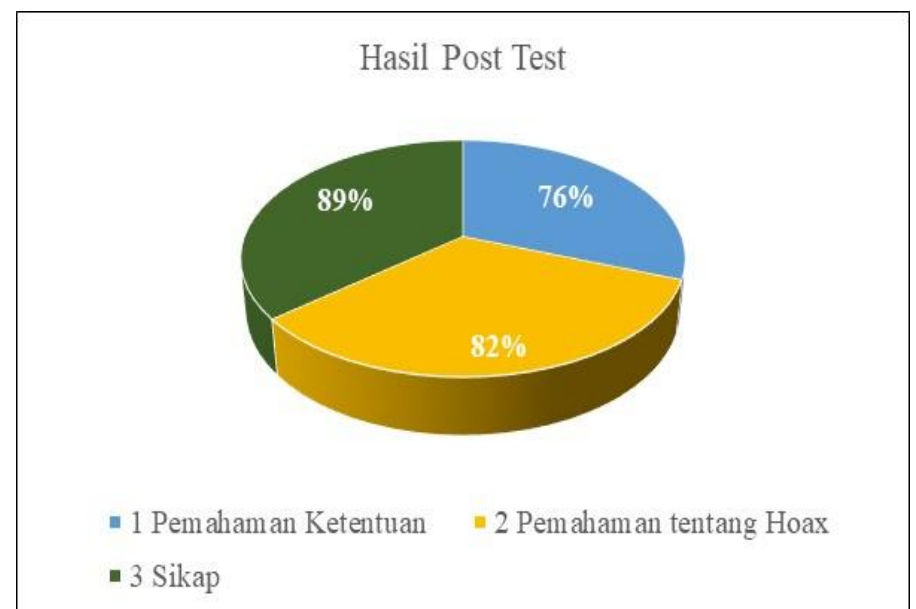

Gambar 2: Hasil post test (Sumber: Analisis pre test PkM, 2021)

c. Pengukuran Tingkat Keberhasilan

Perbandingan hasil pre test dan post test menunjukkan tingkat kenaikan rata-rata $>20 \%$, artinya unggah pesan yang dilakukan oleh anggota dalam grup WA dapat memengaruhi tingkat pengetahuan dan sikap anggota grup lainnya. Tingkat keberhasilan yang diperoleh merupakan selisih antara hasil pre test sebelum materi diunggah yang sebagian besar anggota grup sudah mengetahui terkait hoax dan sikap bermedia sosial seperti pada gambar 3 .

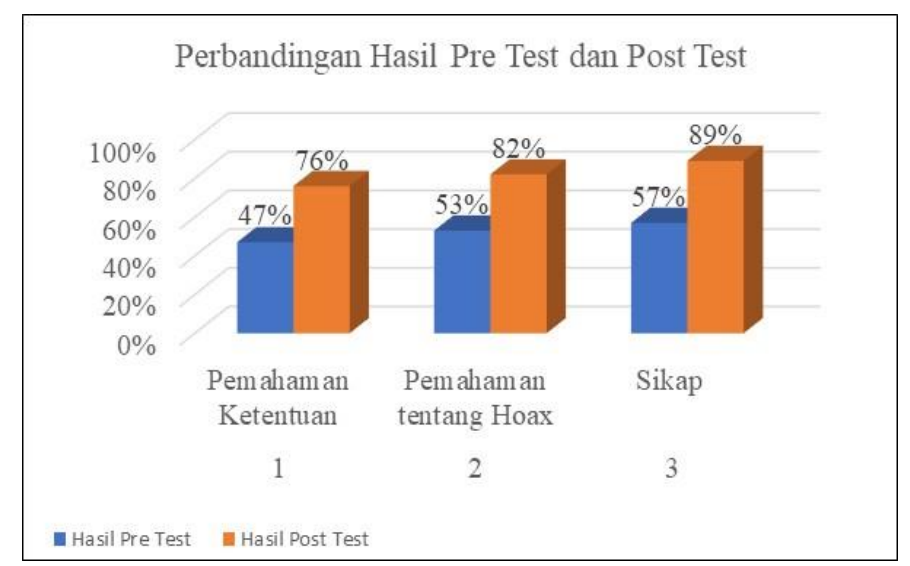

Gambar 3: Perbandingan Hasil pre test dan post test

(Sumber: Analisis pre test PkM, 2021)

Karakteristik anggota grup WA dengan latar belakang pendidikan serta status pekerjaan yang lebih banyak bekerja memberikan kontribusi terhadap perolehan pengetahuan tentang ho.aks. Tingkat respon yang tidak maksimal sangat terkait dengan keterbatasan waktu kegiatan, sehingga meskipun materi diunggah secara berulang selama $4 \mathrm{x}$ tetapi tidak seluruh anggota grup membaca dan memberikan respon. Tingkat kesibukan, waktu serta jumlah kepemilikan grup di media sosial juga menentukan anggota dapat membaca dan merespon setiap informasi 
di media sosial. Peningkatan hasil pre test dan post test menunjukkan bahwa apapun informasi yang diunggah pada media sosial dan dibaca dapat memberikan kontribusi terhadap perubahan aspek kognitif, afektif serta konatif seseorang apalagi informasi dikemas dengan menarik. Tingkat validitas keberhasilan yang diperoleh terkait dengan kepercayaan antar anggota dalam grup, sehingga sumber menjadi penting bagi terjadinya respon. Respon pada pengukuran tingkat keberhasilan dilakukan berdasarkan postingan komentar dan tanggapan terhadap pesan materi yang disampaikan. Materi disampaikan secara berulang $4 \mathrm{x}$ sehingga respon dibuat rerata dari ke 4 unggahan materi.

Tingkat keberhasilan menunjukkan bahwa ho.aks akan terus berkembang dan sangat tergantung kepada pengguna media sosial, yang secara tidak langsung turut menyebarluaskan. Sebagai masyarakat media pembatasan penggunaan media sosial sesuai kebutuhan dan prioritas membantu kita untuk mengendalikan ho.aks, namun saat pandemi penggunaan media sosial tidak dapat dihindari sehingga bijak dalam bermedia sosial merupakan kunci sehat secara psikologis dengan mencermati seluruh informasi yang masuk dan tidak meneruskan informasi tersebut jika mengandung ciri-ciri ho.aks. Ho.aks tidak dapat dihilangkan, tetapi dapat diminimalisir oleh penggunanya dengan pembatasan penggunaan, mencari informasi pembanding, menggunakan media dengan bijak (Sinaga, 2019), atau memenfaatkan media sosial untuk kepentingan yang positif misalnya sebagai peluang wirausaha di kalangan ibu-ibu PKK (Runtuwewe, 2018)

\section{SIMPULAN}

Hasil kegiatan PkM dalam bentuk penyuluhan secara daring tentang pengenalan ho.aks, ketentuan penyebarluasan ho.aks dalam media sosial serta sikap kelompok ibu PKK yang diukur berdasarkan perbandingan hasil pre test dan pos test menunjukkan hasil yang positif dengan tingkat peningkatan $>20 \%$ mengingat waktu penyuluhan dan pengunggahan materi yang terbatas.

Sasaran lebih lanjut adalah penyebarluasan pemahaman kelompok ibu-ibu PKK sesuai fungsinya dalam keluarga yang meliputi pendampingan pembelajaran on line, pengawasan dan pendampingan penggunaan media sosial di lingkungan keluarga khususnya serta pengendalian penyebar luasan informasi ho.aks pada grup media sosialnya.

\section{Ucapan Terima Kasih}

Terima kasih untuk Ketua kelompok ibu-ibu PKK serta seluruh partisipan yang telah berkenan meluangkan waktu berpartisi dalam penyuluhan secara daring maupun dalam pengisian pre test dan post test.

\section{Daftar Pustaka}

Cindoswari, A. R., Syastra, M. T., Patli, M., Putri, D. M. I. (2020). Peningkatan Kemampuan Literasi Media pada Warga Belajar PKBM Sumber Ilmu di Kota Batam. Abdi Moestopo: Jurnal Pengabdian pada Masyarakat, 3 (1), 1-8. https://doi.org/10.32509/am.v3i01.975

Ganggi, R.I.P.(2018). Materi Pokok dalam Literasi Media Sosial sebagai salah Satu Upaya Mewujudkan Masyarakat yang Kritis dalam Bermedia Sosial. Anuva 2 (4), 337345.https://doi.org/10.14710/anuva.2.4.337-345

Gumilar, G., Adiprasetio, J. dan Maharani, N. (2017). Literasi Media: Cerdas Menggunakan Media Sosial Dalam Menanggulangi Berita Palsu (Hoax) Oleh Siswa SMA. Jurnal Pengabdian Kepada Masyarakat, 1(1), 35-40. http://jurnal.unpad.ac.id/pkm/article/view/16275/7939

Hamzah, R. E. \& Putri, C. E.. (2020). Mengenal dan Mengantisipasi Hoax di Media Sosial pada Kalangan Pelajar. Abdi Moestopo: Jurnal Pengabdian Pada Masyarakat, 3 (1), 9-12. https://doi.org/10.32509/am.v3i01.1361 
Monggilo, ZMZ. (2020). Analisis Konten Kualitatif Hoaks Dan Literasi Digital Dalam @ Komikfunday. Interaksi: Jurnal Ilmu Komunikasi, 9 (1), 1-18. https ://ejournal.Undip.ac.id/index.php/interaksi

Novianti, R. \& Riyanto, S. (2018). Tingkat Literasi Media Remaja Desa Dalam Pemanfaatan Internet. Jurnal Komunikasi Pembangunan, $16 \quad$ (2), 158-171. https://doi.org/10.46937/16201825628

Nurmala R. (2018). Pemanfaatan Internet Sebagai Media E-Learning Untuk Siswa Dan Guru Smpn 3 Tarakan. Jurnal Pengabdian Masyarakat Borneo, 2 (2), 21-24. //jurnal.borneo.ac.id / index. php /jpmb/article/ view/518/289

Rahmawan, D., Wibowo, S.K.A., Maryani, E. (2018). Pelatihan Literasi Media Sosial Terkait Penanggulangan Hoaks Bagi Siswa SMA Kabupaten Bandung Barat. Jurnal Pengabdian kepada Mayarakat, 2 (12), 1-5. http://jurnal.unpad.ac.id/pkm/article/view/20404/9799

Rahmawati, A \& Krisanjaya. (2019). Literasi Media Untuk Mengantisipasi Berita Palsu (Hoax) Di Media Sosial Bagi Masyarakat Pulau Tidung Kepulauan Seribu. Sarwahita : Jurnal Pengabdian Kepada Masyarakat, $16 \quad$ (1), 68-74. https://doi.org/10.21009/sarwahita.161.07

Runtuwewe, J.P.A. (2018). Ibm Pada Ibu-Ibu Tim Penggerak Pkk Kota Manado Melalui Pelatihan Pengelolaan Internet Sebagai Sumber Informasi Untuk Keluarga Dan Peluang $\begin{array}{lllll}\text { Wirausaha. } & \text { Jurnal } & \text { Abdimas, } & \text { 95-101. }\end{array}$ http://ejournal.unima.ac.id/index.php/abdimas/article/view/880

Setyawati, N.W., Supriyanto, Darmanto, A. (2020). Penyuluhan Pendampingan Orang Tua Terhadap Putra/Putri Dalam Penggunaan Bijak Bersosmed. Jurnal Pengabdian Masyarakat Ilmu Terapan, 2 (2), 213-218. http://ojs.uho.ac. id/index.php/JPMIT/article/view/11063

Sinaga, K., Junaidi, Saragi, S., Batoebara, M.U. (2019). Pelatihan Meminimalisir Efek Hoaks Media Sosial di Desa Namo Sialang Kecamatan Batang Serangan Kabupaten Langkat, Sumatera Utara. E-Dimas : Jurnal Pengabdian kepada Masyarakat, 10 ( 2 ) , 150159.https://dx.doi.org/10.26877/e-dimas.v10i2.3257.

Undang Undang Nomor 11 Tahun 2008 tentang Informasi dan Taransaksi Elektronik

Undang Undang nomor 19 Tahun 2016 tentang Perubahan atas Unadang Undang Nomor 11 Tahun 2008

CNN Indonesia, 30 januari 2021, 11:10 WIB Pandemic Fatigue, Kelelahan Mental Karena Pandemi, https://www.cnnindonesia.com/

Farissa, F.C. dan Galih. Kompas.com, 2019; " Ini Empat Ciri Hoaks Menurut Kominfo.."https://nasional.kompas.com/read/2019/08/20/14512191/ini - empat - cirihoaks-menurut-kominfo.

Kompasiana, 2020, 14 Agustus 14:54; 16: 15; Maraknya Berita Hoax di Saat Pandemi Covid19, ttps://www.kompasiana.com/alyshachmad /5c07efda6ddcae24f301bff9/ pentingnya-literasi - media - sosial - terhadap -masyarakat?page=all, 5 Desember 2018 